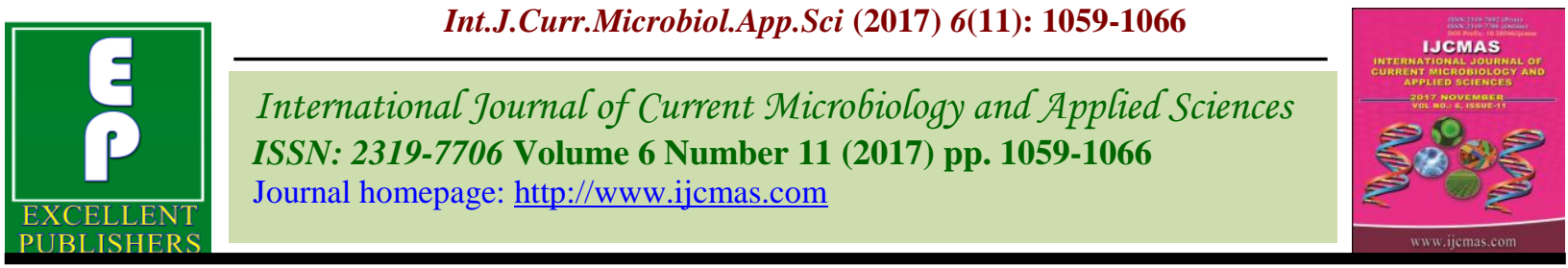

Original Research Article

https://doi.org/10.20546/ijcmas.2017.611.124

\title{
Effect of a Wonder Herb Azolla on Buffaloes Milk Yield
}

\author{
Bacchu Singh", G.S. Meena, K.C. Meena, R.K. Meena, Bachchu Singh and Deepa Indoria \\ Krishi Vigyan Kendra, Hindaun, Karauli, Rajasthan, India \\ *Corresponding author
}

A B S T R A C T

Azolla is a free floating, rapidly growing aquatic fern on water surface. It is one of the most nutritive aquatic plants, owing to its high protein and carotenoid contents and of generally good amino acid profile. Traditional supplements based on oilseed cakes are expensive and cannot fulfill the required nutrients to animals. Forage-based economical feeding strategies are required to reduce production cost of quality livestock products. Productivity of dairy animals largely depends of efficient feeding management. The Scientists of Krishi Vigyan Kendra Karouli introduced azolla in villages of District by demonstration conducted at farmers' field. The farmers were trend by on and off campus practical training on azolla production technology. Thereafter, a survey was conducted in different villages where demonstrations of azolla were established by KVK Scientists and an On Farm Trail was conducted to study the effect of a wonder herb azolla on buffaloes milk yield. For this purpose 20 lactating buffaloes of first to third lactation of 4 to 8 years old at mid lactation were selected and divided into two groups of ten animals in each. The control group (C) farmers practice was fed wheat straw with mustard oilseed cake, whereas the treatment group (T) was fed framers practice with supplementation of $2 \mathrm{Kg}$ fresh green azolla pinnata. The feeding trial lasted for three months. During the trial milk yield were recorded and found the milk yield was significantly higher in treatment group.

\section{Introduction}

Livestock production is the backbone of the Indian economy and has been a source of employment in rural areas for centuries. Ruminants play a major role in providing nutritional and livelihood security for millions of rural households in India. The demand of milk is increasing for nutrition of population in country. In traditional supplements based the farmers fed only oilseed cake as concentrate or unbalanced concentrate ration without any consideration about quality and quantity of feed. The only single cake or unbalanced concentrate ration cannot fulfill the nutrient requirement of animal.
They fed the cake only to milking animals and do not fed to heifers, dry, pregnant and male animals because the cakes are expensive. Therefore, their animals suffer by many problems like- Late maturity, Low milk yield, Short milking period, Long dry period, Milk fever, Prolapsed of Uterus, Repeat breeding etc. Among many factors governing the livestock productivity, feeding accounts for more than $60-70 \%$ of the total recurring cost and hence qualitative and quantitative improvement in this aspect will usually improve productivity. There is acute shortage of feed and fodder for dairy animals due to 
lack of land availability for growing fodder for animals and high population density. The shortage of fodder is therefore, compensated with the use of readymade commercial feed resulting in increased cost of milk production. There is ample scope for improving the productivity of livestock by better balancing of nutrients and optimizing the utilization of feed resources. The search of alternatives to green fodder and concentrates led to a wonderful plant Azolla, which holds the promise of providing a sustainable feed for livestock.

Azolla is a free floating, rapidly growing aquatic fern on water surface. It floats on the surface of water by means of numerous, small, closely overlapping scale-like leaves, with their roots hanging in the water. They form a symbiotic relationship with the cyanobacterium Anabaena azollae, which fixes atmospheric nitrogen. Under ideal conditions it grows exponentially, doubling its biomass in every three days. It produces more than 4 to 5 times of protein of excellent quality in comparison to hybrid napier and lucern, respectively. Azolla has been used successfully as a protein supplement to dairy animals. There are at least eight species of azolla worldwide: Azolla caroliniana, Azolla circinata, Azolla japonica, Azolla mexicana, Azolla microphylla, Azolla nilotica, Azolla pinnata and Azolla rubra. The common species of Azolla in India are Azolla pinnata. It grows naturally in stagnant water of river, canal, pond etc, (Senthilkumar and Manivannam, 2016).

Green plants have long been recognized as the cheapest and most abundant potential source of proteins because of their ability to synthesize amino acids from a wide range of virtually unlimited and readily available primary materials. Azolla is very rich in proteins, essential amino acids, vitamins (vitamin A, vitamin B12, Beta Carotene), growth promoter intermediaries and minerals including calcium, phosphorous, potassium, ferrous, copper, magnesium. On a dry weight basis, Azolla has $25-35 \%$ protein content, 10$15 \%$ mineral content, and 7-10\% comprising a combination of amino acids, bio-active substances and biopolymers (Kamalasanana et al., 2002). Azolla's carbohydrate and oil content are very low. Azolla is also rich in iron (1000-8600 ppm dry weight), copper (3210 ppm dry weight) manganese (120-2700 ppm dry weight), vitamin A (300-600 ppm dry weight), vitamin A (300-600 ppm dry weigh), chlorophyll and carotenes. It contains 4.8-6.7\% dry weight crude fat, with $6.1-7.7 \%$ and $12.8-26.4 \%$ total fat for the polyunsaturated acids omega 3 and omega 6 .

Azolla meal contains $25.78 \%$ crude protein, $15.71 \%$ crude fiber, $3.47 \%$ ether extract, $15.76 \%$ ash and $30.08 \%$ nitrogen free extract on the air-dry basis (Basak et al., 2002). In addition, aquatic plant species including azolla do not to accumulate secondary plant compounds and therefore has a greater potential than tree leaves to source protein for monogastric animals. One hectare of azolla can produce $540-720 \mathrm{~kg}$ of protein per month. Azolla has been reported as one of the most economic and efficient feed substitutes for livestock, particularly as can be easily digested by livestock due to its high protein and low lignin content. Azolla is called "Green Gold" due to these characteristics (Wagner, 1997).

The objective of the present study was to evaluate the use of Azolla meal as feed supplement in the diet of buffaloes in rural India, where animal keepers used only oilseed cakes as concentrate ration.

\section{Materials and Methods}

The present study was carried out in 2016-17 by establishing 120 azolla production units 
covering in 12 villages spread across Hindaun, Karouli, Nadoti and Todabhim Tehsils of District Karouli, Rajasthan by Scientists of Krishi Vigyan Kendra Krouli (Picture 1-3). The livestock owners were proper trend by on and off campus practical training on azolla production technology (Picture 4). Regular monitoring was done and suggestions were given to rectify the minor problems in azolla cultivation. Thereafter, a survey was conducted to assess the feeding, milk production and physical health status of animals in different villages where azolla production units were established and an On Farm Trail was conducted to study the effect of a wonder herb azolla on buffaloes milk yield. For this purpose 20 lactating buffaloes of first to third lactation of 4 to 8 years old at mid lactation were selected for the study and randomly distributed into two groups of ten animals in each. The standard management practice was grazing for 8-10 hours.

The buffaloes were hand-milked twice daily. Daily milk yield of each animal was recorded for a period of 3 months. The control group (C) farmers practice was fed wheat straw with mustard oilseed cake, whereas the treatment group (T) was fed with same quantity of roughages and concentrate with supplementation of $2 \mathrm{Kg}$ fresh green azolla pinnata (Picture 5-6). The feeding trial lasted for three months. During the trial daily milk yield were recorded and physical health status of animals were observed.

\section{Azolla production}

An artificial water body is made, preferably under the shade of a tree, with the help of a silpauline sheet. The Dimensions of pits were $3 \mathrm{M} \times 1.5 \mathrm{M} \times 0.2 \mathrm{M}$. This pit is covered with plastic gunnies to prevent the roots of the nearby trees piercing the silpauline sheet, which is spread over the plastic gunnies to prevent filtration of water. The size of the sheet was $0.5 \mathrm{~m}$ longer and wider than the pit and was secured by a layer of mud at the edges. About $10-15 \mathrm{kgs}$ of sieved fertile soil was uniformly spread over the silpauline sheet. Slurry made of 2-kg cow dung and 30 gms of Super Phosphate in 10 liters water, was poured into the pit. More water was poured to make the water level reach about 10 $\mathrm{cm}$. About $1 \mathrm{~kg}$ of fresh and pure culture of azolla is inoculated in the pit (Picture 7). Growth was rapid (environmental temperature ranged within 30 to $35^{\circ} \mathrm{C}$ ) and within 10-15 days azolla had covered the pit area. About $1 \mathrm{~kg}$ of lush green azolla was harvested daily in a plastic tray having holes of 1 sq.cm mesh size to drain the water. Then it was thoroughly washed twice to get rid of the cow dung smell/ammoniacal smell. The small plantlets which drain out along with water in the bucket were poured back in to the original bed. Thus, the collected fresh azolla 2 $\mathrm{kg}$ /day/animal was mixed in concentrate (oilseed cake) and fed to the lactating buffaloes. A mixture of 20 gms of Super Phosphate and about $1 \mathrm{~kg}$ of dung suspension were added once in 5 days. About $5 \mathrm{~kg}$ bed soil was replaced with fresh soil, once in 30 days to avoid nitrogen build up and prevent micronutrient deficiency.

Twenty five to 30 per cent water was replaced with fresh water in 10 days to prevent nitrogen build up in the bed. This was did to keep the azolla in rapid multiplication phase and to maintain the daily yield of $1 \mathrm{~kg}$./pit. Generally, azolla requires $25-50$ per cent of full sunlight for its normal growth. The optimum temperature was $20-30^{\circ}$ C. The optimum relative humidity was 85 to 90 per cent. The optimum $\mathrm{pH}$ was 5.5-7 (VKNARDEP, 2010). Azolla biomass 350-399 gms/sqm should be removed daily to avoid overcrowding and for keeping the fern at rapid multiplication (Gouri et al., 2012). They also observed that the farmer can harvest up to 750 tons of azolla from one acre. 
Picture.1 Establishing Azolla units at farmer's field

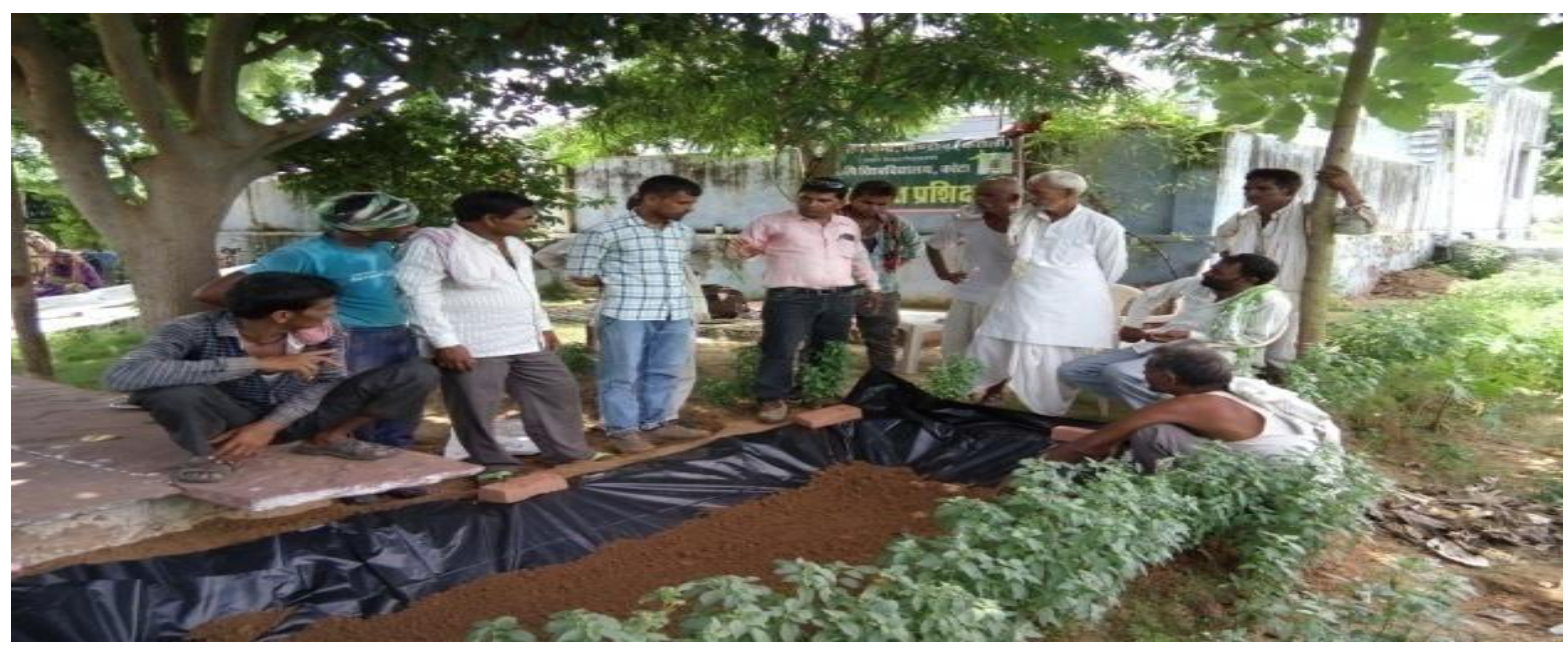

Picture.2 Establishing Azolla units at farmer's field

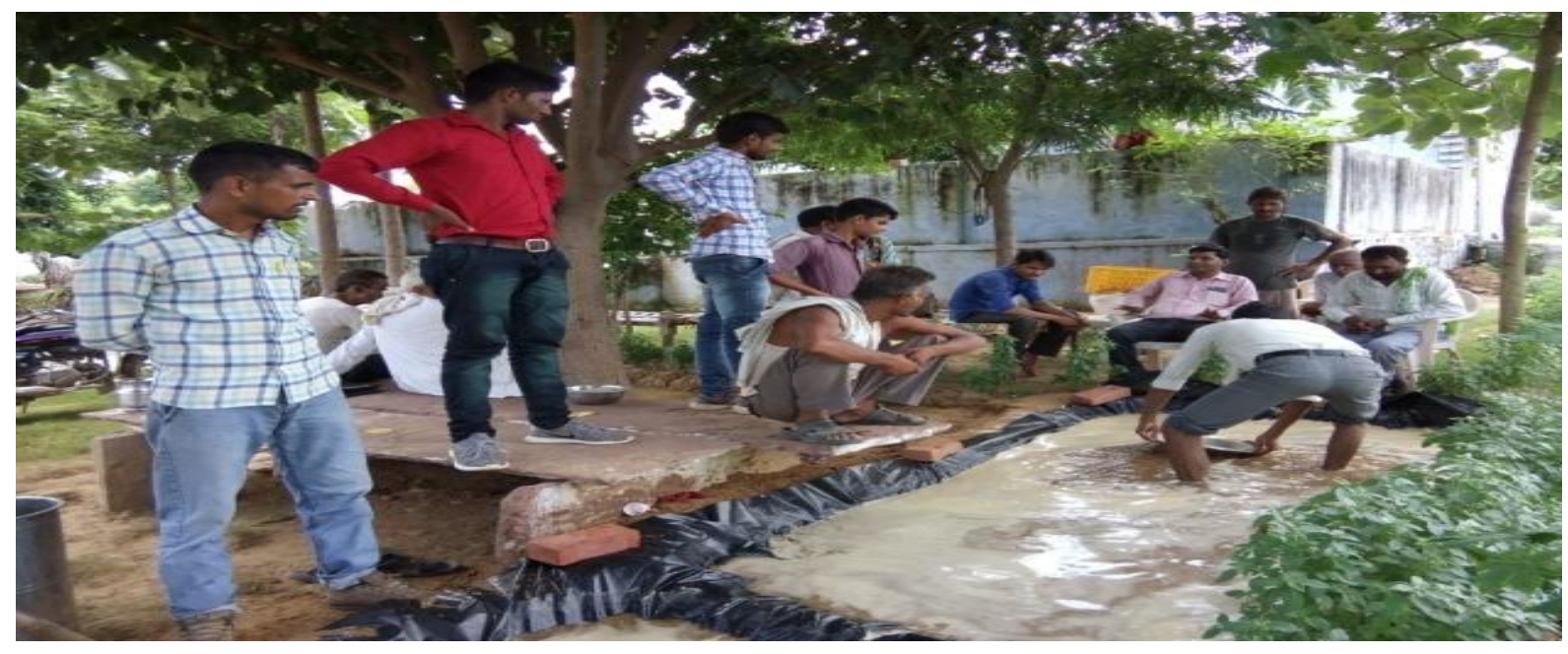

Picture.3 Establishing Azolla units at farmer's field

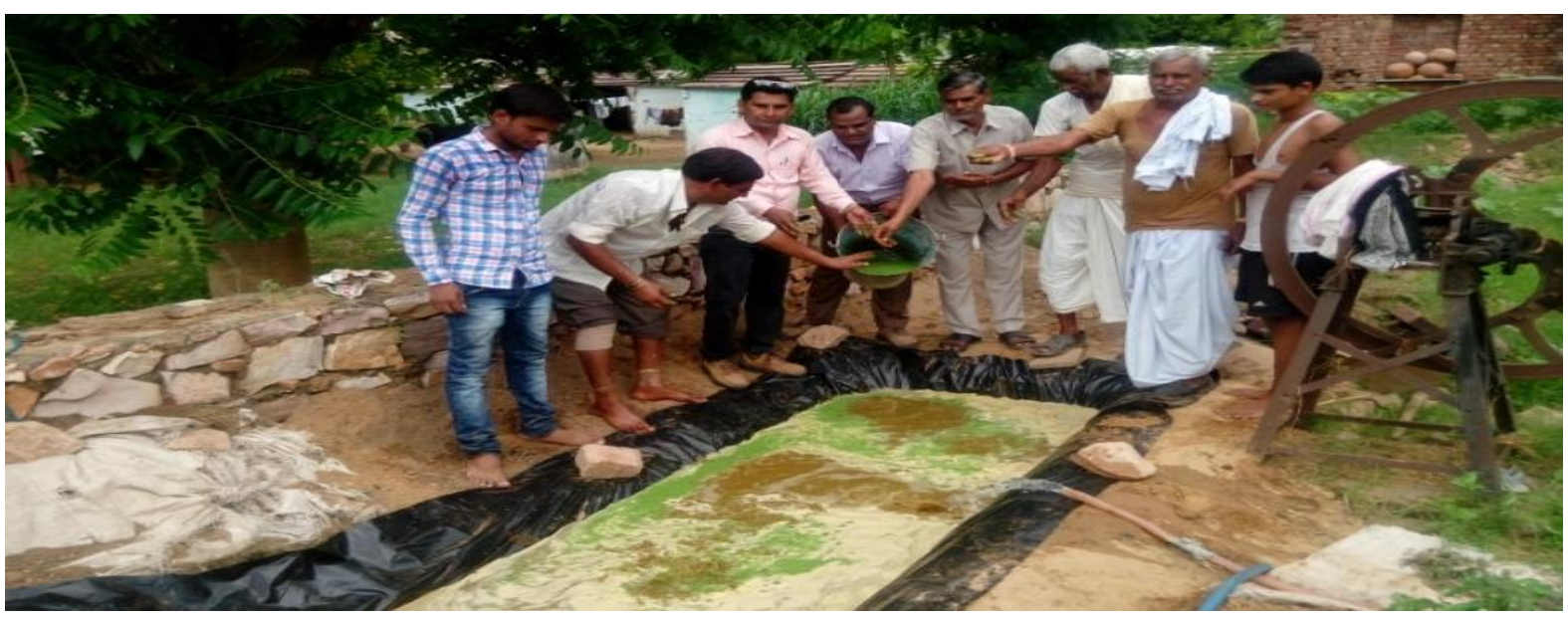


Picture.4 Practical training to farmers by KVK Scientists

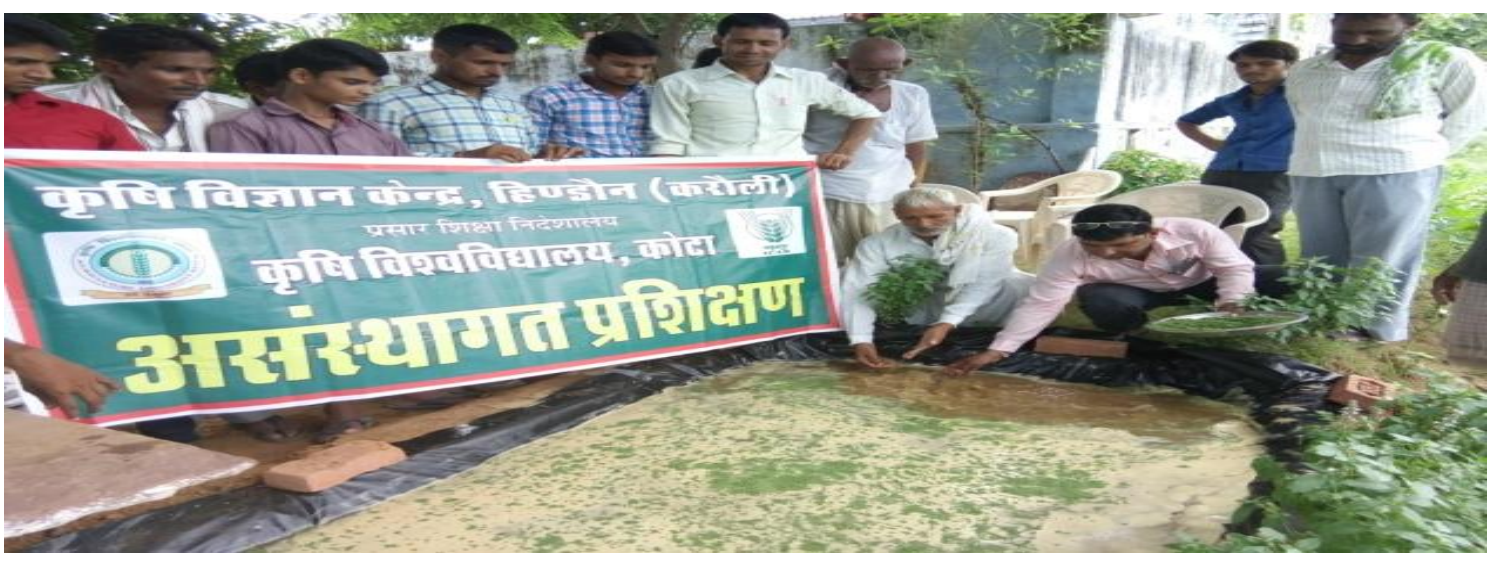

Picture.5 Harvesting of Azolla for animal feeding

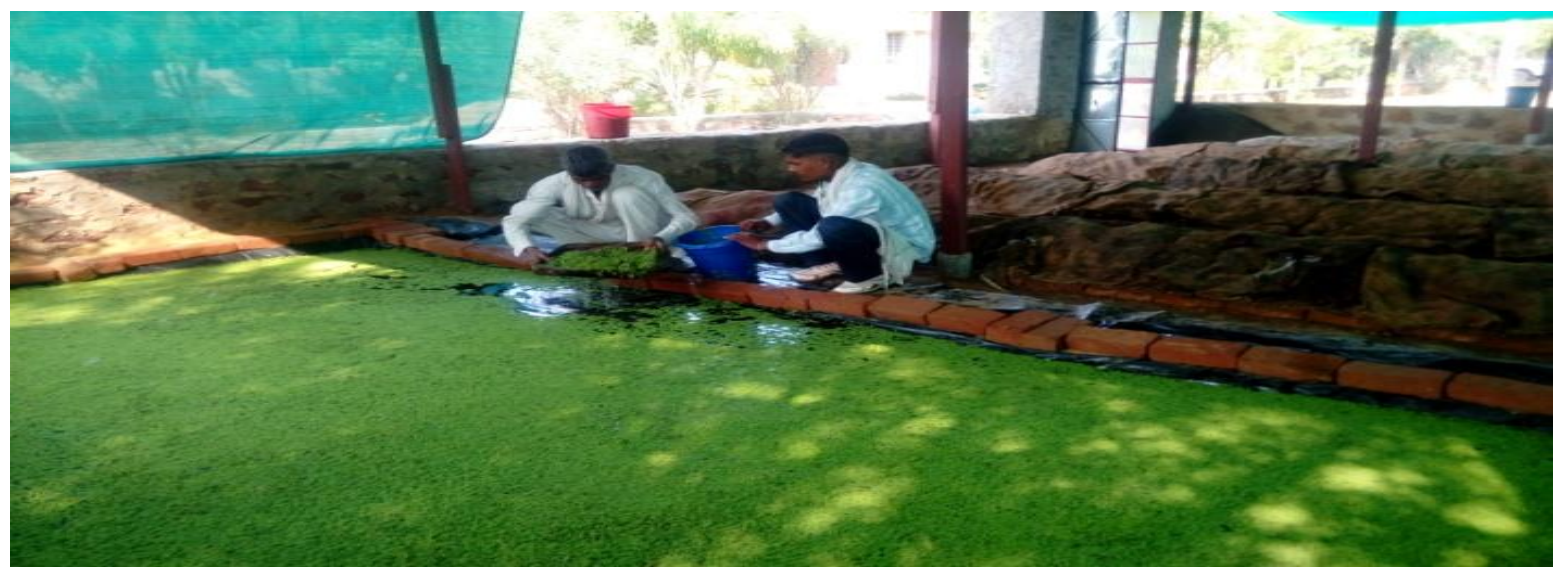

Picture.6 Feeding Azolla to buffaloes

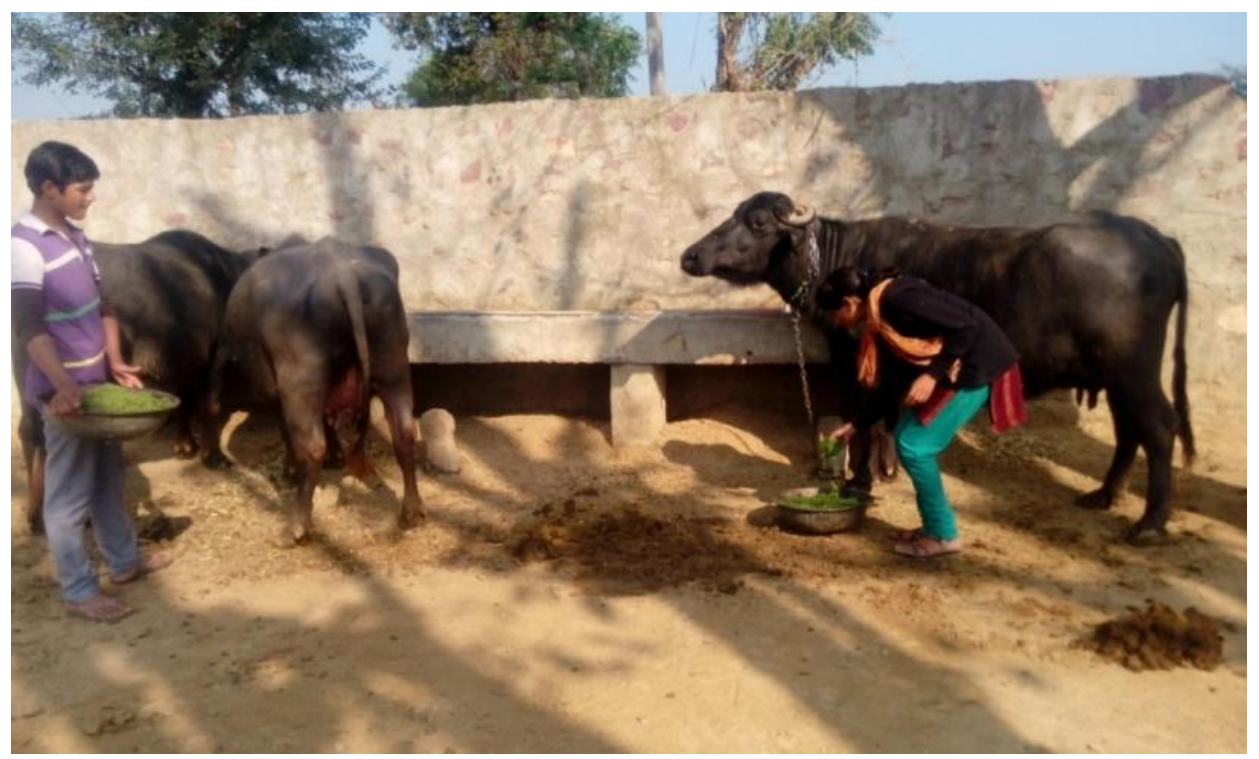


Picture.7 Azolla demonstration unit at KVK Hindaun

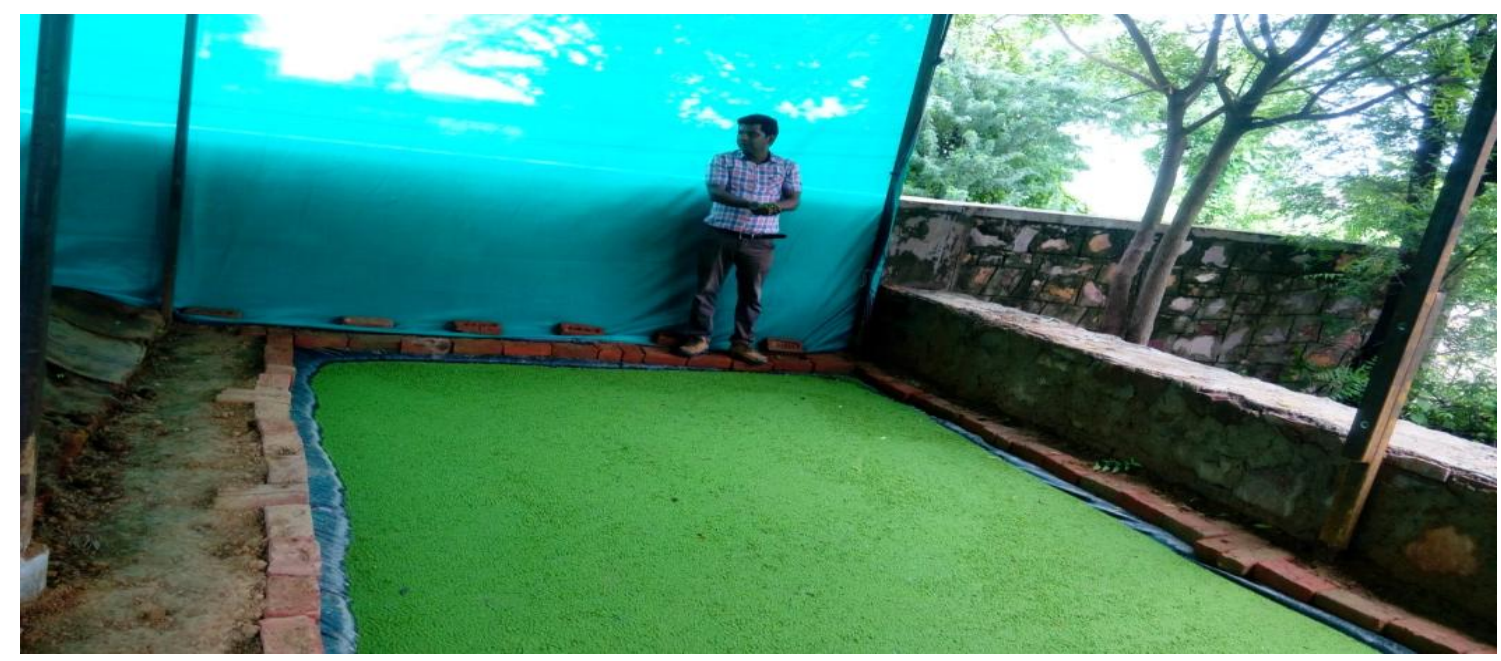

Treatment details

\begin{tabular}{|l|l|l|}
\hline $\begin{array}{l}\text { S. } \\
\text { No. }\end{array}$ & Treatments & $\begin{array}{l}\text { Milk Yield } \\
\text { (Lit./Day) }\end{array}$ \\
\hline $\mathbf{1}$ & $\begin{array}{l}\text { T1 = As per farmers' practice (Wheat straw, grass, Lucerne, Chicory and } \\
\text { mustard cake) }\end{array}$ & $\mathbf{8 . 8 0}$ \\
\hline $\mathbf{2}$ & $\begin{array}{l}\text { T2= T1 + Deficiency of nutrients was fulfilled by providing green azolla } \\
\text { meal (2.0Kg/day/animal) }\end{array}$ & $\mathbf{1 0 . 5 0}$ \\
\hline $\mathbf{3}$ & Average Increase & $\mathbf{1 . 7 0}$ \\
\hline $\mathbf{4}$ & \% Increase & $\mathbf{1 9 . 3 2}$ \\
\hline
\end{tabular}

\section{Results and Discussion}

Many researchers (Khutan et al., 1999; Satish and Ustuge, 2009 and Tamang and Samanta, 1993) have identified many unconventional feed and fodder to maintain the milk production particularly in off season. Azolla holds the promise of providing a sustainable feed for livestock. The present study was undertaken to know effect of feeding azolla on milk yield of lactating buffaloes under field conditions. The milk yield was higher in buffaloes fed azolla with mustard oilseed cake in comparison to control group fed only mustard oilseed cake. The milk yield showed increasing trend and it increased to $10.5 \mathrm{~L} /$ day from $8.8 \mathrm{~L} /$ day after 90 days of feeding $2 \mathrm{Kg}$ azolla per day with conventional feed Mustard oilseed cake. On an average milk yield increase by 1.70 L/day. About $19.32 \%$ increase in the milk yield is a tremendous improvement. It is in conformation with Mathur et al., (2013) and Kamalasanana et al., (2002) in buffaloes. Whereas, Kololgi et al., (2009) found $10 \%$ increase in milk yield in lactating buffaloes. Gouri et al., (2012), Ambade et al., (2010), Rawat et al., (2015) and Gowda et al., (2015) found similar results in cross bred cows. In contrast Murthy et al., (2013) found no significant difference among the groups with respect to milk yield in crossbred cows. Sanginga and Van Hove, (1989) reported that the main character influencing the value of azolla as its feed is its amino acid composition. In Various studies revealed that the azolla can be fed to these animals without any adverse effects. In this study, in azolla fed group has not only 
increased the milk yield but also increase in physical status and reproductive efficiency. It is concluded that feeding fresh azolla with mustard oilseed cake enhanced the milk production and the animal starts showing excellent sign of health, such as improved hair coat condition, brightness in eyes, moist muzzle and always activeness after feeding of azolla. Therefore, it can be used as a valuable green feed supplement for buffaloes, particularly under low input livestock production system, where livestock owners fed only oilseed cake as concentrate or unbalanced concentrate ration, because the only single cake or unbalanced concentrate ration cannot fulfill the nutrient requirement of animal. Azolla can fulfill the requirement of nutrients of animal with mustard oilseed cake. Therefore, the livestock owners may fed it to all ruminant animals on all stages of growth and production and the problems likeLate maturity, Low milk yield, Short milking period, Long dry period, Milk fever, Prolapsed of Uterus, Repeat breeding etc. may overcome. Azolla is important for animal health and milk production. So we can produce more milk from indigenous buffaloes at low cost.

\section{References}

Ambade R B, Jadhav S N and Phalke N B (2010) Impact of azolla as a protein supplement and its Influence on feed utilization in livestock. Livestock line. 4(4): 21-23.

Basak B, Pramanik AH, Rahman MS, Tarafdar SU, Roy BC (2002) Azolla (Azolla pinnata) as a feed ingredient in broiler ration. Inj J Poult Sci 1(3):29-34.

Gouri Mahadevappa D, Sanganal Jagadeesh S, Gopinath CR, and Kalibavi CM (2012) Importance of azolla as a sustainable feed for livestock and poultry. Agric Review. 33(2):93-103.
Valleesha NC, Maya G, Pal DT, Suresh KP (2015) Azolla (Azolla pinnata) as a Green Feed Supplement for Dairy Cattle-An On Farm Study. Anim Nutr Feed Tech: 15(2): 283-287.

Kamalasanana P, Premalatha S, and Rajamony S, (2002). Azolla - A sustainable feed substitute for livestock. Leisa India. March 2002, pp 15-17.

Khutan A, and Ali MA (1999) Comparision of nutritive value for laying hens of diets containing azolla (Azolla pinnata) based on formulation using digestible protein and digestible amino acid versus total protein and total amino acid. Anim Feed Sci Tech 81(1-2): 43-56.

Kololgi SD, Hosamani SV, Malshet Karuna and Nagraj MS (2009) Azolla an organic feed supplement feed for livestock. National symposium on Organix Livestock Farming- Globle issue, trends and challenges, 26-28 Feb, Kotkata, pp35.

Mathur GN, Sharma Ramakant and Choudhary PC (2013). Use of Azolla (Azolla pinnata) as Cattle Feed Supplement. J. Krishi Vigyan 2 (1):7375.

Murthy TNK, Ashok M, Thirumalesh T, Umesh BU, Nataraju OR (2013). Effect of partial replacement of Azolla for concentrate supplement on lactating crossbred cows. J Env Ecol 31(2):415417.

Rawat Nidhi, Kumari K, Singh F, Gilhare VR (2015). Effect of Azolla-supplemented feeding on milk production of cattle and production performance of broilers. Applied Biological Research. 17 (2): (214- 218).

Sanginga N and Vanhove C (1989) Aminoacid composition of azolla as affected by strain and population density. J Plant and Soil. 117(2): 263267.

Gowda NKS, Manegar A, Verma S, Satish B and Ustuge SM (2009) Azolla 
production and livestock feeding. National symposium on Organix Livestock Farming- Globle issue, trends and challenges, 26-28 Feb, Kotkata, $\mathrm{pp} 21$.

Senthilkumar S and Manivannam C (2016) Adoption of azolla cultivation technology in the framers field: An analysis. Inter $\mathrm{J}$ Sci Env Tech 5(5):3081-3087.

Tamang Y and Samanta G (1993) Feeding value of azolla (Azolla pinnata) an aquatic fern in Black Bengal goats. Indian J Anim Sci 63 (2): 188-191.

VK-NARDEP (2010) Azolla Backyard cultivation: Innovation and ecological significance. http://vknardep.org/services/ sustainable-agriculture/81-azolla-forthe-rescue.html.

Wagner GM (1997) Azolla: A review of its biology and utilization. Botani Review 63(1):1-26.

\section{How to cite this article:}

Bacchu Singh, G.S. Meena, K.C. Meena, R.K. Meena, Bachchu Singh and Deepa Indoria. 2017. Effect of a Wonder Herb Azolla on Buffaloes Milk Yield. Int.J.Curr.Microbiol.App.Sci. 6(11): 1059-1066. doi: https://doi.org/10.20546/ijcmas.2017.611.124 